\title{
Development and storage characteristics of shrimp (Solenocera crassicornis) based snack food using extrusion technology
}

\author{
K. G. Baraiya ${ }^{1}$, S. M. Zofair ${ }^{1}$, V. B. Mulye ${ }^{1}$, S. R. Lende ${ }^{2}$, R. A. Khileri ${ }^{3}$, R.M. Kadri ${ }^{4}$, A. \\ K. Jha ${ }^{4}$ and M.R. Patel ${ }^{5}$ \\ ${ }^{1}$ Department of Harvest and Post-Harvest Technology, College of Fisheries, Junagadh Agricultural University, \\ Veraval-362 265 (Gujarat), INDIA \\ ${ }^{2}$ Department of Aquaculture, Kamdhenu University, Gandhinagar- 382010 (Gujarat), INDIA \\ ${ }^{3}$ Department of Fisheries Resource Management, College of Fisheries, Junagadh Agricultural University, Veraval- \\ 362265(Gujarat), INDIA \\ ${ }^{4}$ Central Institute of Fisheries Technology, Veraval-362269 (Gujarat), INDIA \\ ${ }^{5}$ Department of Aquaculture, College of Fisheries, Maharana Pratap University of Agriculture and Technology, \\ Udaipur-313001(Rajasthan), INDIA \\ *Corresponding author. E-mail: kirenbaraiya011@gmail.com
}

Received: December 27, 2015; Revised received: May 09, 2016; Accepted: July 25, 2016

Abstract: An attempt was made to develop nutrient rich extruded snacks from lesser utilized protein rich shrimp (Solenocera crassicornis) flour using twin screw extruder. The extruded were in order to fried and packed in to High Density Polyethelene (HDPE). The extruded were analyzed for physical, texture profile, proximate composition and sensory characteristics at the interval of 10 days for 50 days of storage (DOS). The experiment shows the physical property like expansion ratio $(\mathrm{mm})$ and texture profile characteristics such as hardness (gmF) and crispiness (gm) were not affected at the end of storage period. Among the different studies, the product made from rice/shrimp T1 based extruded scored as higher as 5 (out of 5 ) by sensory evaluation for all attributes. Consequently, all the extruded were maintained the physical properties, nutritional quality and overall acceptability. This research demonstrated that shrimp flour at $15 \%$ can be successfully incorporated for development of extruded were: expansion ratio 3.32, 2.75 and $3.06(\mathrm{~mm})$, crispiness 291, 252 and $210(\mathrm{gm})$, protein 12.69, 18.74 and $15.09(\%)$, enegy value 540, 489 and 524 (Kcal), TPC 0.36, 0.34 and 0.34 (log cfu/gm) in rice T1, wheat T2 and corn T3 based extruded respectively. Overall, the quality assessment of extruded were not changed significantly $(P>0.05)$ throughout study.

Keywords: Extrusion cooking, Quality change, Solenocera crassicornis, Snack food, Storage stability

\section{INTRODUCTION}

Food and Agricultural Organization (FAO, 2011) estimated that ten percent of the total catch consists of fish that are underutilized because of undesirable features like small size, dark meat, high fat content, strong flavour, high bone content, unacceptable textural properties, and/or the possible presence of toxic substances. Utilization of low-value fishes is of great importance in developing countries. However, due to the undesirable features mentioned above, underutilized fishes are discarded rather than consumed. Processing these fishes using High Temperature Short Time (HTST), called extrusion cooking, will help modify the texture and other physical properties and make them suitable for human consumption.

Demand for extruded types of novel products is increasing significantly in developing countries. Extruded exhibits better nutritional quality compared to other traditional cooked products (Singh et al., 2007). Extruded snack like products are mostly cereal-based and developed mainly from cereal like corn, wheat, rice and maize etc. The current snacks market studies indicate that extruded products is shifting from baby foods to the adult market which needs to improve the eating quality with respect to texture, color, flavor and most importantly the nutritional facts. With the growing demand for convenience foods, sales of ready to cook and ready to eat packaged foods are constantly on the rise (Shah, 1991). Many snacks are high in carbohydrate and fat but low in protein, vitamins, and other nutrients. It can be made nutritionally rich with increased protein content and nutritional value by adding high-quality protein sources including legumes (peanut, soybean and cowpea) as well as fish, pork, beef, and chicken. Incorporation of protein rich food into cereal based snack by using extrusion cooking would not only rectify its nutritional inadequacies, but also provide a variety of food products. Many attempts have been made by food researcher to improve protein quality of Ready-to-eat (RTE) snacks with incorporation of legume, isolated proteins or defatted soy flour, ISSN : 0974-9411 (Print), 2231-5209 (Online) All Rights Reserved @ Applied and Natural Science Foundation www.jans.ansfoundation.org 
meat and cheese analogues (Lakshmidevi et al., 2005; Veronica et al., 2006).

In modern days, there is an ever increasing awareness about health foods and fish is gaining more acceptances because of its nutritional and functional properties. Maintaining and increasing the nutritional quality of fish based product during food processing is always a potentially important area for research. Fish are not only excellent source of high nutritional value protein but also excellent sources of lipids that contain omega3 fatty acids, especially, Eicosapantaenoic Acid (EPA) and Decosahexaenoic Acid (DHA) (Simopoulos, 2000). The omega-3 fatty acids are essential for normal growth and may prevent coronary artery disease, hypertension, diabetes and cancer. Interestingly, fish is also a good source of various vitamins $\left(\mathrm{A}, \mathrm{D}, \mathrm{B}_{6}\right.$, and $B_{12}$ ) and minerals (iron, zinc, iodine, selenium, potassium, sodium etc.). These potential effects have gained the attention of food processor, the medical community and consumer and have promoted diverse products containing n-3 fatty acids (Augustin and Sanguasri, 2003). The fish based studies have been reported successful incorporation of fish powder into starch-based materials by extrusion process to produce extruded products that were acceptable by consumer (Suknark et al., 2001; Shaviklo et al., 2011). One of the primary benefits of extrusion is that it can transform a highly perishable initial product into a shelf-stable food.

The coastal mud shrimp (Solenocera crassicornis) is a local variety of shrimp which is used as food items in the coastal areas of Gujarat, India. It contains $20.83 \%$ protein, $1.05 \%$ fat, $77.20 \%$ moisture, $1.53 \%$ ash and a good amount of minerals. Large amount of coastal mud shrimp is wasted every year due to lack of proper preservation and utilization method which can be considered as protein ingredient in snack food development. Extrusion process has been considered potential solution to utilization of the low economic value shrimp by using twin screw extrusion process. Thus, the economic and nutritional value of snack product will be greatly enhanced with addition of shrimp in the recipe. Success of shrimp and rice, wheat and corn based snack food will not only enhance the better utilization of low value shrimp but also enhances nutritional value of such snack food produced as well as opening a new avenue for local entrepreneurship. The aim of this study was to formulate nutritionally enriched stable, low cost snacks using locally available resources.

\section{MATERIALS AND METHODS}

Procurement of raw material: The shrimp caught by trawl net along the coast off Veraval, Gujarat (Lat- $20^{\circ}$ $55^{\prime} 12^{\prime \prime} \mathrm{N}$ and long-70'20'24'E) were used for the study. The shrimp were iced in the ratio of $1: 1$ (shrimp: ice) and transported to the laboratory. The whole shrimp were washed in chilled potable water and processed to convert peeled and deveined (PUD).
It was dried in mechanical drier (Sun instruments Inc.) at $60^{\circ} \mathrm{C}$ for $8 \mathrm{hrs}$ and ground into powder with a blender (Mixer grinder, HP 1651 Philips) in order to sieved with $4 \mathrm{~mm}$ mesh size. Rice flour, wheat flour, corn flour and food color were procured from the local market and in order to sieve with $4 \mathrm{~mm}$ mesh size to remove large sized grain particles. While other ingredients such as sunflower oil, salt, chili powder, chat masala, garam masala and other materials were procured from same local market for frying process.

Extruder: The extruder machine used for the present study was the twin-screw extruder (SYSLG-IV, Jinan Saibainuo Machinery Co. Ltd, China). Whole machine dimension length, width and depth are $2 \mathrm{~m}, 0.7 \mathrm{~m}, 1.4$ $\mathrm{m}$ respectively. The dimension of screw were $30 \mathrm{~mm}$ in diameter and $600 \mathrm{~mm}$ long. While the pitch of the screw was $80 \mathrm{~mm}$ with a flight depth of $4 \mathrm{~mm}$.

Formulation of dough: The products were prepared using a blend of rice flour/wheat flour/corn flour along with shrimp powder. The initial moisture content of rice flour, wheat flour and corn flour were 5.5\%, 7.5\% and $6.5 \%$ respectively. The flours were mixed with shrimp flour at $15 \%(\mathrm{w} / \mathrm{w})$ level and adjusted the final moisture by adding required amount of water, conditioned at room temperature for $24 \mathrm{hrs}$. The blend was then mixed with sodium chloride and food color at $2 \%$ (w/w) and $0.06 \%(w / w)$ level respectively. Then the mixture was thoroughly mixed and then sieved through the $4 \mathrm{~mm}$ mesh to get uniform particle size and then kept for equilibration time of $30 \mathrm{~min}$. After equilibration, once again the sample were sieved and mixture was prepared for extrusion as a function of barrel temperature, screw speed and die diameter. Feeding rate of cereal - shrimp flour mixture was adjusted to $333 \mathrm{~g} /$ $\min (20 \mathrm{Kg} / \mathrm{hr})$.

Extrusion Process: The mixture was prepared as a function of barrel temperature at 4 sections barrel were maintained at $30^{\circ}, 60^{\circ}, 130^{\circ}$, and $160^{\circ} \mathrm{C}$. The machine parameters such as screw motor, feeder motor and cutter motor were maintained at a speed of 480, 240,180 rpm respectively and $2 \mathrm{~mm}$ die diameter was used. The mixtures were continuously fed to the machine by minimum of 4 min running time was allotted between treatments to ensure equilibrium before representative samples were taken. Finally the samples were collected on the aluminum tray and dried at $60^{\circ} \mathrm{C}$ for 1 hour in mechanical drier.

Frying Process: The products were fried at $180^{\circ} \mathrm{C}$ for $15 \mathrm{sec}$ and allowed to drain excess oil, cooled at ambient temperature. Taste enhancers such as table salt, chili powder, chat masala and garam masala at $1.71 \%$, $2.85 \%, 0.78 \%$ and $0.28 \%(\mathrm{w} / \mathrm{w})$ respectively were added and mixed uniformly to enhance taste the product. The finished extruded were packed into self-sealed High Density Polyethylene (HDPE) pouches and were analyzed for physical, chemical and sensory characteristic at interval of 10, 20, 30, 40 and 50 days. 
Determination of Product Response expansion ratio (ER): was determined by the cross-sectional diameter of the extruded measured with a Vernier caliper. The ER values were obtained from 5 random samples with three locations in each sample. The ER was calculated as the cross-sectional diameter of the extruded divided by the diameter of the die opening and expressed as percentage (Ding et al., 2005).

$$
\text { Expansion ratio }=\frac{\text { Diameter of extruied sample }}{\text { Die diameter }} \times 100
$$

Bulk density (BD) was determined by weighing the quantity of $5 \mathrm{~cm}$ long pieces required to fill a $500 \mathrm{ml}$ beaker (Hood- Niefer and Tyler, 2010). The extruded pieces were randomly added to the container and the container was shaken several times during filling. The $\mathrm{BD}$ was then calculated using the following formula, assuming a cylindrical shape of extruded.

$$
\mathrm{BD}\left(\mathrm{g} / \mathrm{cm}^{3}\right)=\frac{M}{V}
$$

Where, $\mathrm{M}$ is mass ( $\mathrm{g}$ ) and $\mathrm{V}$ is the volume of beaker in $\mathrm{cm}^{3}$. The experiment was done in triplicate from each treatment replication.

Particle density (PD) was calculated according to the method of Gujska and Khan (1990). Individual cylindrical extruded rods were weighed individually; the diameter and length were measured by using Vernier calliper:

Particle density $\left(\mathrm{g} / \mathrm{cm}^{3}\right)=\frac{4 \mathrm{~m}}{\frac{4 d^{2} \mathrm{I}}{2}} \mathrm{le} \mathrm{ng} \mathrm{th}$
Where, $\mathrm{m}$ and $\mathrm{L}$ are rod mass $(\mathrm{g})$ and $(\mathrm{cm})$, respectively, of extruded with diameter $\mathrm{d}(\mathrm{cm})$. The experiment was done in triplicate for each treatment replication.

Porosity (PO) was calculated according to Wang et al. (1999) using the following calculation.

$$
\text { Porosity }=\frac{\text { Fartile densiry -auk density }}{\text { Fartikle density }} \times 100
$$

Colour: The colour of the sample were determined using a colour reader (CR-10, Konica Minolta Sensing, Inc., made in Japan). The sample were ground in to powder using a mixer. A uniform thick layer of the powder was taken in the sample holder of the colorimeter and values corresponding to $L^{*}, a^{*}$ and $b^{*}$ were measured. The measurement were carried out in single for each treatment replication.

Texture profile analysis: Texture analysis of sample were carried out using the CT3 texture analyser (Brookfield engineering laboratories, Inc. USA). After a trigger force of $3 \mathrm{gm}$ was attained the probe then proceeded to penetrate into the sample to a depth of 4 $\mathrm{mm}$. At this depth the maximum force reading (the resistance to penetration) was obtained and measured as hardness, crispiness, quality of fracture, cohesiveness, springiness and chewiness of the product.

Compositional analysis: The moisture content of the sample were measured using moisture balance meter (Mac 110 N/H, EU) according to AOAC (2006) stan- dard method. The crude protein content of the samples was estimated using Microkjeldal method AOAC (2006). The amount of fat in the sample was determined using soxhlet method AOAC (2006). Ash content of the sample was estimated by AOAC (2006) method. Carbohydrate content was estimated by the difference (Left content after rest of composition). The energy values of the extruded were determined by computation and expressed in kilo calories.

Microbiological analysis: Determination of TPC and $S$. aureus were measured in all products using standard method recommended by AOAC (2006).

Sensory analysis: Sensory evaluations were conducted using a ten panel members. Panelists were trained to evaluate the extruded for general appearance, surface texture, flavour, crispiness and overall acceptability on a 0-5 Hedonic scale (Larmond, 1977) and the results were averaged.

Statistical analysis: The results were subjected to statically analysis of variance (ANOVA). IBM BASIC windows release 1.13 was used to know the significant difference for different treatment combination and to find the best treatment combination. Mean and SD for four replicates were calculated Completely Randomized Design (CRD). Significant $(p<0.05)$ differences between means were determined by Duncan's post hoc test using SPSS release 16.0.0.

\section{RESULTS AND DISCUSSION}

Characteristics of raw material: In the present study, shrimp characteristics were evaluated the proximate composition such as moisture, protein, fat and ash of fresh shrimp were recorded to $77.2 \%, 20.83,1.05 \%$ and $1.53 \%$ respectively. The chemical characteristics such as TMA-N and TVB-N were found as 2.70 (mg $\%)$ and $8.10(\mathrm{mg} \%)$ respectively, while TPC was noted as $4.0 \pm 0.41 \mathrm{log} \mathrm{cfu} / \mathrm{g}$. The results obtained from present study indicates that the shrimp were fresh and good quality. Homchoudhury et al. (2012) analyzed the proximate composition of shrimp (Metapeneopsis stridulans) were as $20 \%$ of protein, $1.5 \%$ of ash, $1 \%$ of fat and $76 \%$ of moisture. However, the slight variation noted in present study might be due to different species, size, weight and season. The characteristics found in shrimp were in agreement with the reports given by earlier researchers. (Virgilo et al., 2006; Erickson et al., 2007; Ali et al., 2013).

The proximate compositions of cereal flour used for extrusion are shown in Table 1. The proximate composition of rice flour used in the present study is similar with the results of the literature (Madhusudhan and Tharanathan, 1995; Spigno and Faveri, 2004) were reported that the protein content of rice flour varies between $5.85-8.2 \%$ and the fat content varies between $0.56-1.4$ percent. The wheat flour used in the present study revealed the protein content was higher (12.37 $\%)$ as compared to that of rice or corn flours. While the 
Table 1. Proximate composition of flours used in the present study.

\begin{tabular}{|c|c|c|c|c|c|}
\hline \multirow{2}{*}{$\begin{array}{l}\text { Sr. } \\
\text { No }\end{array}$} & \multirow{2}{*}{$\begin{array}{l}\text { Proximate Composi- } \\
\text { tion }\end{array}$} & \multicolumn{4}{|c|}{ Mean \pm SD } \\
\hline & & Rice flour & Wheat flour & Corn flour & Shrimp flour \\
\hline 1 & Moisture (\%) & $5.50^{\mathrm{a}} \pm 0.100$ & $10.33^{c} \pm 0.153$ & $7.90^{\mathrm{b}} \pm 0.095$ & $9.10^{c} \pm 0.125$ \\
\hline 2 & Total Protein $(\%)$ & $6.83^{b} \pm 0.058$ & $12.37^{\mathrm{c}} \pm 0.153$ & $5.56^{\mathrm{a}} \pm 0.067$ & $86.15^{\mathrm{d}} \pm 0.109$ \\
\hline 3 & Total Fat (\%) & $0.31^{\mathrm{a}} \pm 0.015$ & $1.40^{\mathrm{c}} \pm 0.100$ & $1.46^{\mathrm{c}} \pm 0.061$ & $1.25^{\mathrm{b}} \pm 0.090$ \\
\hline 4 & Total Ash (\%) & $2.00^{\mathrm{b}} \pm 0.100$ & $1.00^{\mathrm{a}} \pm 0.100$ & $0.53^{\mathrm{a}} \pm 0.058$ & $2.23^{\mathrm{c}} \pm 0.055$ \\
\hline 5 & Carbohydrate & $85.01^{\mathrm{c}} \pm 0.326$ & $74.28^{\mathrm{b}} \pm 0.076$ & $83.78^{\mathrm{c}} \pm 0.153$ & $0.70^{\mathrm{a}} \pm 0.049$ \\
\hline
\end{tabular}

Mean values in column for all the samples with different superscripts are significantly different

$(p<0.05)$.Value are expressed as mean $\pm \mathrm{SD}, \mathrm{n}=4$. (\%, wet basis).

Table 2. Changes in expansion ratio $(\mathrm{mm})$ of extruded snack products during storage period.

\begin{tabular}{cccc}
\hline \multirow{2}{*}{ DOS } & \multicolumn{3}{c}{ Rice, wheat and corn flour extruded with shrimp flour } \\
\cline { 2 - 4 } & T1(Rice) & T2 (Wheat) & T3 (Corn) \\
\hline 0 & $3.32^{\mathrm{Aa}} \pm 0.099$ & $2.75^{\mathrm{Ac}} \pm 0.070$ & $3.06^{\mathrm{Ab}} \pm 0.102$ \\
10 & $3.30^{\mathrm{Aa}} \pm 0.034$ & $2.68^{\mathrm{ABc}} \pm 0.025$ & $3.05^{\mathrm{Ab}} \pm 0.076$ \\
0 & $3.25^{\mathrm{Aa}} \pm 0.156$ & $2.66^{\mathrm{BCc}} \pm 0.047$ & $3.00^{\mathrm{ABb}} \pm 0.025$ \\
30 & $3.22^{\mathrm{ABa}} \pm 0.107$ & $2.62^{\mathrm{BCc}} \pm 0.077$ & $2.96^{\mathrm{ABCb}} \pm 0.116$ \\
40 & $3.16^{\mathrm{ABa}} \pm 0.085$ & $2.62^{\mathrm{BCc}} \pm 0.040$ & $2.90^{\mathrm{BCb}} \pm 0.049$ \\
50 & $3.07^{\mathrm{Ba}} \pm 0.021$ & $2.59^{\mathrm{Cc}} \pm 0.057$ & $2.85^{\mathrm{Cb}} \pm 0.105$ \\
C.D. at 5\% & & $\mathrm{NS}$ & \\
CV (\%) & & 2.732 & \\
\hline
\end{tabular}

Different superscript in capital letters $(\mathrm{A}, \mathrm{B}, \mathrm{C})$ indicate significant difference $(p<0.05)$ amongst rows and superscripts in small letters $(a, b, c)$ indicate significant difference amongst column. Value are expressed as mean \pm SD $(n=4)$. NS=Not significant.

Table 3. Changes in bulk density and porosity of extruded product during storage period.

\begin{tabular}{|c|c|c|c|c|c|c|}
\hline \multirow{3}{*}{ DOS } & \multicolumn{3}{|c|}{ Bulk density $\left(\mathrm{g} / \mathrm{cm}^{3}\right)$} & \multicolumn{3}{|c|}{ Porosity $(\%)$} \\
\hline & \multicolumn{6}{|c|}{ Rice, wheat and corn flour extruded with shrimp flour } \\
\hline & T1 (Rice) & T2 (Wheat) & T3 (Corn) & T1(Rice) & T2 (Wheat) & T3 (Corn) \\
\hline 0 & $0.23^{\mathrm{Cab}} \pm 0.03$ & $0.24^{\mathrm{Aa}} \pm 0.07$ & $0.22^{\mathrm{CDb}} \pm 0.04$ & $57.167^{\mathrm{Aa}} \pm 5.33$ & $62.04^{\mathrm{Aa}} \pm 1.29$ & $53.31^{\mathrm{Ab}} \pm 0.93$ \\
\hline 10 & $0.23^{\mathrm{Cb}} \pm 0.02$ & $0.24^{\mathrm{Aa}} \pm 0.05$ & $0.22^{\mathrm{Dc}} \pm 0.05$ & $49.91^{\mathrm{Bb}} \pm 2.99$ & $55.49^{\mathrm{Ba}} \pm 4.67$ & $51.62^{\mathrm{Ab}} \pm 1.91$ \\
\hline 20 & $0.24^{\mathrm{Ba}} \pm 0.04$ & $0.24^{\mathrm{Aab}} \pm 0.03$ & $0.23^{\mathrm{BCb}} \pm 0.07$ & $48.29^{\mathrm{BCa}} \pm 6.54$ & $54.44^{\mathrm{Ba}} \pm 4.20$ & $46.63^{\mathrm{Ba}} \pm 4.33$ \\
\hline 30 & $0.24^{\mathrm{Cab}} \pm 0.05$ & $0.24^{\mathrm{Aa}} \pm 0.02$ & $0.23^{\mathrm{BCb}} \pm 0.02$ & $42.84^{\mathrm{CDb}} \pm 1.67$ & $53.87^{\mathrm{Ba}} \pm 3.12$ & $43.72^{\mathrm{Bb}} \pm 1.30$ \\
\hline 40 & $0.24^{\mathrm{Ba}} \pm 0.06$ & $0.24^{\mathrm{Aa}} \pm 0.00$ & $0.24^{\mathrm{Aa}} \pm 0.14$ & $37.09^{\mathrm{DEc}} \pm 4.87$ & $53.62^{\mathrm{Ba}} \pm 2.48$ & $43.42^{\mathrm{Bb}} \pm 1.46$ \\
\hline 50 & $0.26^{\mathrm{Aa}} \pm 0.06$ & $0.24^{\mathrm{Ab}} \pm 0.00$ & $0.24^{\mathrm{Ab}} \pm 0.02$ & $32.02^{\mathrm{Eb}} \pm 0.97$ & $44.51^{\mathrm{Ca}} \pm 5.59$ & $36.79^{\mathrm{Cb}} \pm 5.88$ \\
\hline $\mathrm{CD}$ at & & & & & $0.008 *$ & \\
\hline $5 \%$ & & $5.371 *$ & & & 0.008 & \\
\hline $\mathrm{CV}(\%)$ & & 7.861 & & & 2.357 & \\
\hline
\end{tabular}

Different superscript in capital letters (A, B, C) indicate significant difference $(p<0.05)$ amongst rows and superscripts in small letters $(a, b, c)$ indicate significant difference amongst column. Value are expressed as mean $\pm S D(n=4)$.

fat content was $1.40 \%$. Even more, Bredie et al. (2002) reported the protein and fat content of $9.5 \%$ and $1.5 \%$ respectively in wheat flour are lesser than present study. The proximate compositions of corn flour were used similar to the result of several workers (Onwulata et al., 2001; Ferreira et al., 2011). The protein content of shrimp flour was $86.15 \%$ which is similar with $82.53 \%$ protein of fish flour reported by Majumdar and Singh (2012).

\section{Quality changes during storage}

Physical characteristics : The diameter of the sample were marginal reduced after 50 days of storage. However, the change were not significant $(p>0.05)$. The diameter of the sample were relatively higher in rice flour based product T1 (6.75 to $5.98 \mathrm{~mm})$ as compared to the wheat based T2 (5.50 to $5.04 \mathrm{~mm}$ ) and corn based extruded T3 (6.24 to $5.77 \mathrm{~mm})$. The result shows that rice based product caught better stability throughout the study. Kuna et al. (2013) also studied the expansion and diameter had relation in respect to same proposition in rice/wheat/corn based product followed by present study.

The sample were slightly gained the weight after 50 days of storage which is perhaps due to increased moisture content with successive days. However, the changes were not significant $(p>0.05)$. The least change was recorded in T1 (0.55 to $0.60 \mathrm{gm})$ as compared to T2 (0.30 to $0.54 \mathrm{gm})$ and $\mathrm{T} 3(0.41$ to $0.51 \mathrm{gm})$. The result supported by Kuna et al. (2013) fish based extruded recorded change in sample weight from 0.2 to $0.4 \mathrm{gm}$.

The expansion ratio of the extruded remained almost 
same throughout storage. A small changes were noted in $\mathrm{T} 1(0.25 \%)$ and T3 $(0.21 \%)$ at end of the storage. But were not significant $(p>0.05)$ (Table 2$)$. The noteworthy change in expansion ratio perhaps due to increasing moisture content with progressively days as discussed above.

The particle density of extruded product recorded the increasing trend with successive the days of storage but the changes were not significant $(p>0.05)$. The change in particle density of product was relatively more pronounced in wheat based sample T2 $(0.43$ to $\left.0.64 \mathrm{gm} / \mathrm{cm}^{3}\right)$ as compared to T1 $\left(0.38\right.$ to $\left.0.57 \mathrm{gm} / \mathrm{cm}^{3}\right)$ and T3 (0.39 to $\left.0.49 \mathrm{gm} / \mathrm{cm}^{3}\right)$. Rice (T1) and corn based (T3) samples were diverged with progressive period of storage which might be related to collapsing of air pocket in the product with increasing moisture content.

The samples varied from initial $57.67 \%$ to $32.02 \%$, $62.04 \%$ to $44.51 \%$ and $53.31 \%$ to $36.79 \%$ in T1, T2 and $\mathrm{T} 3$ respectively for porosity. The result shows that the change in porosity of the product were relatively more marked in rice based product i.e. T2 $(25.65 \%)$ followed by wheat $\mathrm{T} 1(17.33 \%)$ and corn based T3 $(16.52 \%)$. However, all the sample were noted declining significantly $(p<0.05)$ in porosity because of shrink of the product as noted above (Table 3 ). The similar positive linear effect porosity was also reported by Yagci and Goguş (2008) and Hood-Niefer and Tyler (2010), whereas contrasting result was reported by Thymi et al. (2005).

The significant increase $(p<0.05)$ in the bulk density of extruded made of rice (T1) and corn based (T3) were noticed during experiment, whereas wheat based (T2) remained unchanged (Table 3 ). The bulk density and porosity has shown positive correlation which is obvious. Increasing of bulk density in $\mathrm{T} 1$ and $\mathrm{T} 3$ is in agreement with Kumar et al. (2010) showing that increased in moisture content, increased the bulk density of carrot/rice/pulse based product. The opposite behaviors of bulk density and expansion ratio have been reported by Ding et al. (2006). Increased bulk density with increased fat content was observed by Veronica $e t$ al. (2006) in maize/soybean based extruded.

Overall, the changes observed in physical characteristics by slow gain of moisture in the product with progressively days. Chaiyakul et al. (2009) and Tumuluru et al. (2013) reported that moisture content has adverse effect on expansion ratio, bulk density, porosity, hardness, and protein content of fish/rice based product at storage periods.

The color changes by the storage can be considered as an indicator to evaluate the intensity of the process in terms of chemical and nutritional changes (Ilo et al., 1999). The ' $L$ '-value of all the product showed relative stable throughout the storage period as initial ' $L$ '-value (lightness) was 42.65 for $\mathrm{T} 1,49.48$ for $\mathrm{T} 2$ and 48.82 for T3 to to $38.68,45.20$ and 45.55 respectively at the finale. Therefore, changes were not significant $(p>0.05)$.

The changes in ' $a$ ' value of the sample showed 


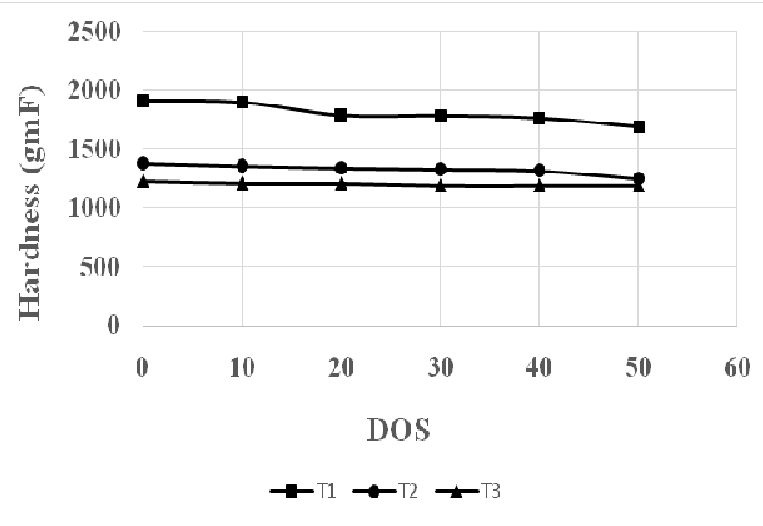

Fig. 1. Changes in hardness (gmF) of extruded product during storage period.

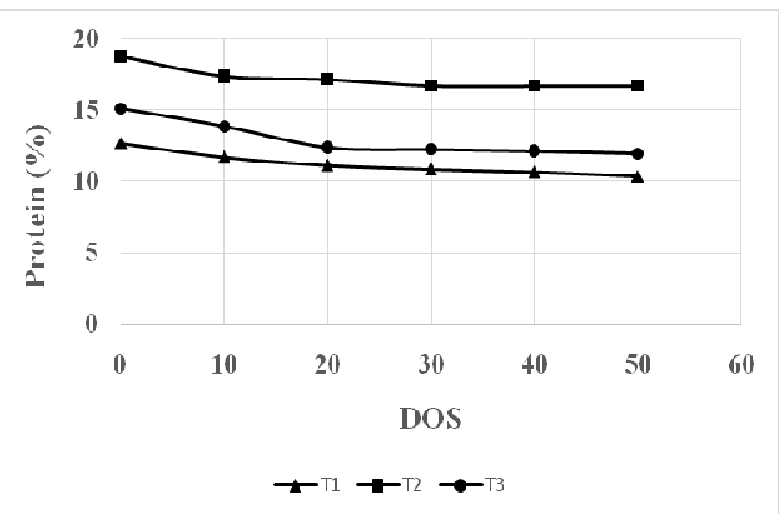

Fig. 3. Changes in protein (\%) of extruded product during storage period.
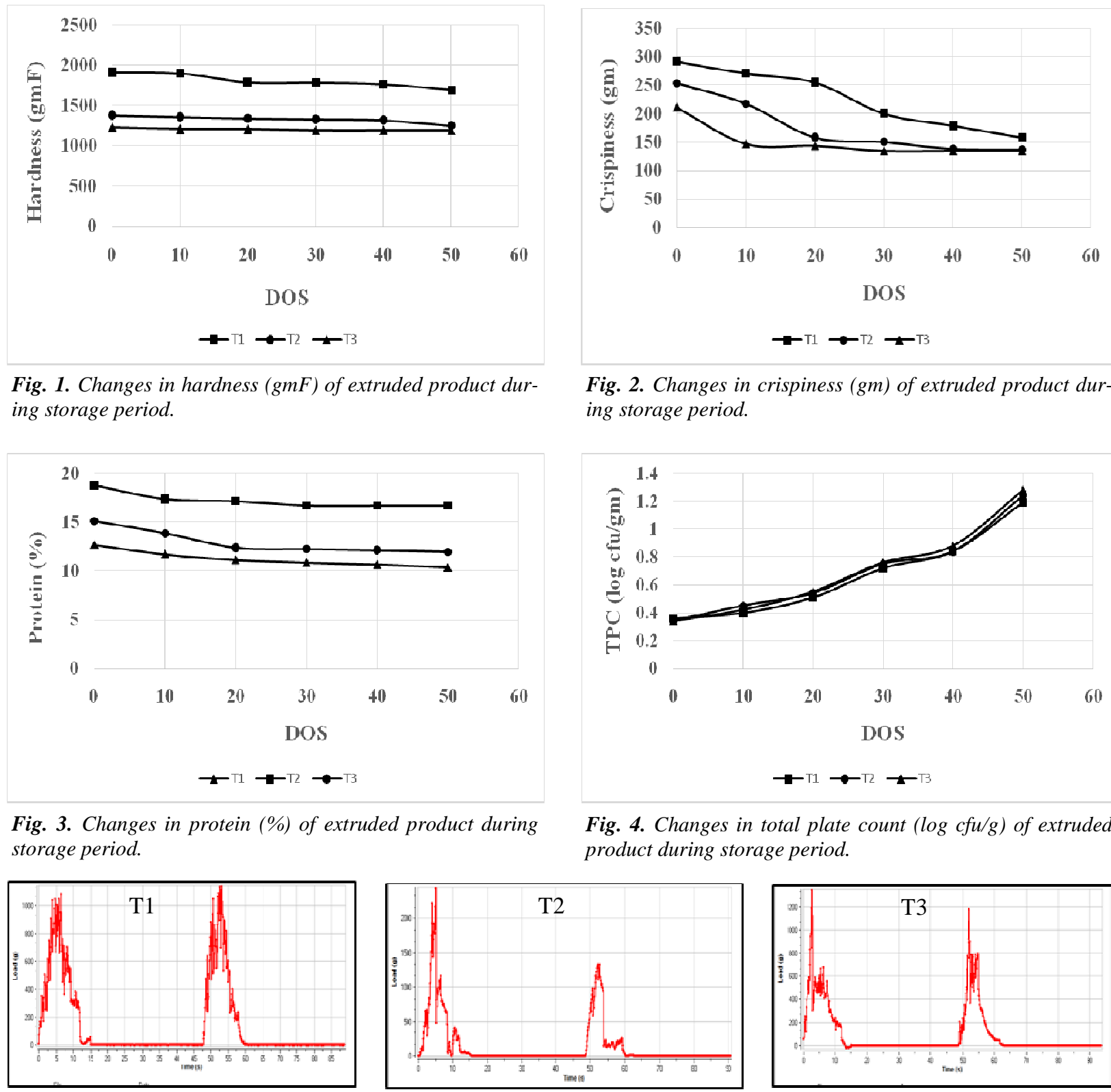

Fig. 2. Changes in crispiness ( $\mathrm{gm}$ ) of extruded product during storage period.

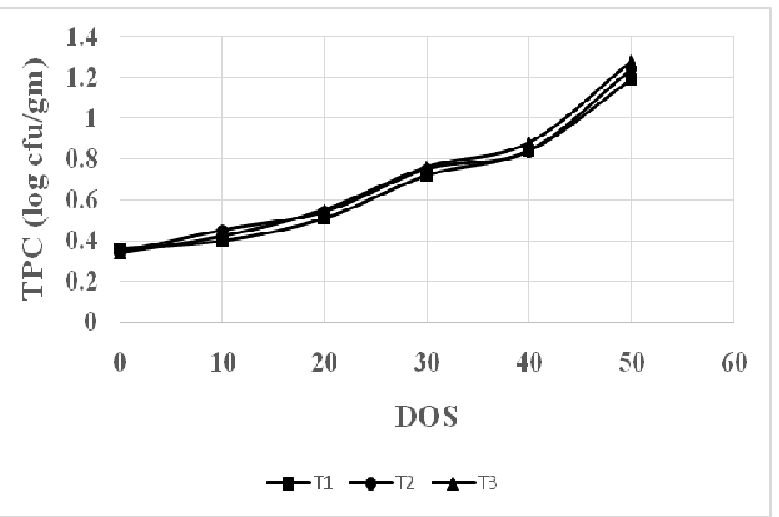

Fig. 4. Changes in total plate count (log cfu/g) of extruded product during storage period.

Fig. 5. Texture profile analysis: Time vs Load

slightly increasing trend as from 13.20 to 13.68 for T1, 13.75 to 14.40 for T2 and 12.68 to 13.68 for T3. The result indicates the product became reddish which argument supported by Shaviklo et al. (2011) reported that changes were influenced by storage time and type of snack. The lightness $\left(L^{*}\right)$, redness $\left(a^{*}\right)$ and yellowness $\left(b^{*}\right)$ of snacks were 33-36, 9-11 and 20-24 respectively for corn-fish extruded. However, changes were not significant $(p>0.05)$.

The ' $b$ '-value of the sample were changed significantly to yellowish $(p<0.05)$. The changes from 19.42 to 22.50 for $\mathrm{T} 1,22.58$ to 24.18 for T2 and 22.28 to 27.88 for T3 during storage period. Least change was observed in $\mathrm{T} 2(1.60 \%)$.

Above all, this might be due to interactive effect of millard reaction with the ingredient present in the sample. The result revealed that insignificant change both in ' $L$ ' and ' $a$ ' value while significant change in ' $b$ ' value that does not alter the overall acceptability of extruded.

Texture profile characteristic: The hardness of the samples decreased gradually (Fig. 1). The higher hardness was noted in T1 (1909.25 to $1689.25 \mathrm{gmF})$ followed by T2 (1377.50 to $1248.25 \mathrm{gmF})$ and T3 (1229 to $1131 \mathrm{gmF})$. Like hardness, the crispiness of the sample have shown the decreasing trend (Fig. 2). The highest crispiness was observed in T1 (291.25 gm) followed by T2 (252.75 gm) and T3 was (210.75 gm), which gradually decreased to $157.75 \mathrm{gm}, 136.50 \mathrm{gm}$ and $123.50 \mathrm{gm}$ after the 50 days of storage period. Maximum changes of quality of fracture was observed 
in $\mathrm{T} 1$ (27.75 to 17.25 no.), while least changed recorded in T2 (25.00 to 21.50 no). The positive correlation was found between loss of crispiness accompanied by loss of quality of fracture, where in obvious. Besides, the maximum cohesiveness change was observed in T2 $(0.52 \%)$, while least changed was recorded in $\mathrm{T} 1(0.23 \%)$. Like cohesiveness, the maximum changes were recorded in $\mathrm{T} 3(6.37$ to $5.51 \mathrm{~mm})$ and $(116.90$ to $68 \mathrm{~mJ})$ in both springiness and chewiness respectively, while least change was in T1 $(6.44$ to $6.13 \mathrm{~mm}$ ) for springiness and T2 (111.15 to 93.63 $\mathrm{mJ}$ ) for chewiness. The graph (Fig. 5) shows the T1 (attained highest peak points) were more superior in texture profile followed by T3 (moderate) and T1 (least) peak point against time vs load.

Compositional characteristics: The moisture content of the samples were raised gradually with progressively periods. The maximum changes were observed in T2 (1.91 to $3.48 \%$ ) followed by T1 (1.52 to $2.40 \%)$ and T3 (1.55 to $2.50 \%$ ) after 50 days. Present study indicates that the moisture content has adverse reaction on expansion ratio, bulk density, porosity, hardness and crispiness of product throughout study. Similar finding with Chaiyakul et al. (2009) and Tumuluru et al. (2013) reported total protein content, expansion ratio, bulk density, hardness and net protein content of fish/rice based extruded were influenced by moisture, which corroborates the present observation. While Shaviklo et al. (2011) reported no changes in moisture content of the product up to 6 month storage of extruded. Perhaps strong moisture barrier packaging material was used. Overall, the changes in the moisture content were significant $(p<0.05)$ by selected packaging material perhaps was not strong barrier against moisture.

The graph shows the protein content of the sample were slightly declined during storage (Fig. 3). Initially the protein content in $\mathrm{T} 1, \mathrm{~T} 2$ and $\mathrm{T} 3$ extruded were $12.69,18.74$ and $15.09 \%$ respectively, which declined to $10.37 \%$ for $\mathrm{T} 1,16.69 \%$ for T2 and $11.95 \%$ for T3 at the end of storage period. The percentage of protein was relatively more in $\mathrm{T} 2$ as compared to $\mathrm{T} 1$ and $\mathrm{T} 3$. This is due to relatively higher protein content in wheat flour than rice and corn flour. No other reports have been found on change of protein of fish based extruded during storage for supportive review.

Unlike protein, the fat content raised sharply throughout study. Maximum significant changes were observed in T3 (28.75 to $38.93 \%$ ), while least changes in T2 $(22.75$ to $27.28 \%)$. Similar the storage study carried by Shaviklo et al. (2011) observed fat content of $30.6-31.7 \%$ in corn snacks after the oil frying process which packed in polypropylene bags at ambient temperature and increased fat content after the 6 months of storage. This apparent increase in fat content with progressive storage is perhaps related to settling of oil in the collapsed air pocket of the product.

The ash content, which is a measure of total mineral in the extruded, remained stable with intermitted fluctuation during storage. The ash content was 2.80 to $270 \%$ for $\mathrm{T} 1,3.75$ to $3.53 \%$ for $\mathrm{T} 2$ and 3.25 to $3.38 \%$ for $\mathrm{T} 3$ during the storage period. The highest ash content recorded $3.75 \%$ in wheat flour (T2) based extruded due to relatively higher ash content in wheat flour than rice and corn flour. Present study showed that changes were more or less stable at the end of storage period.

The carbohydrate content has been shown no notable change during the days of storage. Initially the carbohydrate content in T1, T2 and T3 based extruded was $51.50,53.36$ and $51.36 \%$ respectively. The higher energy value were noted in T3 $(571.12 \mathrm{Kcal})$ followed by T2 (514.65) and T1 (566.1 Kcal) after 50 days.

Microbiological characteristics: Total plate counts are commonly used as an index of spoilage of fish and fishery products. TPC, a measure of bacterial load, in T1 was 0.36 to $0.40 \log \mathrm{cfu} / \mathrm{g}$, which marginally increased during storage period followed by TPC of 0.34 to $1.24 \log \mathrm{cfu} / \mathrm{g}$ in T2 and 0.34 to $1.28 \mathrm{log} \mathrm{cfu} / \mathrm{g}$ in T3 but much below the limit of rejection (Fig. 4). $S$. aureus was not observed throughout study. Absence of $S$. aureus indicated the microbiological safe and stable product at the end of storage period. No microbial growth was detected in crab based extruded up to 3 month storage period in the study carried out by Murphy et al. (2003). Shaviklo et al. (2011) recorded total plate count of less than $1 \times 10^{3} \mathrm{cfu} / \mathrm{g}$ during 6 month storage in corn-fish based snack foods and no E. coli or Salmonella were detected. Microorganisms have been reported to be inhibited by inclusion of salt, sugar and spices in foods (Bamforth, 2005). The same may be reason in present study for restricted growth of bacteria in extruded of kept in safe package.

Sensory characteristics: The researcher (Shoar et al., 2010) said, acceptability depends mainly on the organoleptic properties of the snacks, which are usually measured in terms of texture, taste and appearance. The sensory qualities of $\mathrm{T} 1$ recorded the highest acceptance in term of general appearance, surface texture, crispiness and overall acceptability, but scores slowly decreased with increasing storage period, while T2 scored higher for flavor of the products (Table 4). Kuna et al. (2013) while studying the snacks made from combination of cereal/pulse/fish powder also noted deterioration in sensory quality but were well acceptable in aspect of color, flavor, texture, taste, mouth feel and overall acceptability. The same is the case with the present finding. Therefore, rice flour (T1) coextruded with shrimp flour offers better performance in terms of quality during long term storage at ambient temperature.

\section{Conclusion}

The present study concluded that development of extruded using cereal flour with shrimp flour, without compromising on the quality of final product, would help to improve the nutritional quality of cereal and 
pulse based snack food apart from adding distinct flavor and taste. The underutilized shrimp will not only be utilized for value addition but also for development of products with enhance nutritional value of ready to eat snack foods. Products developed not only acceptable but also physically, chemically and microbiologically stable for 50 days of storage period. On the basis of sensory evaluation, the best product made was rice flour coextruded with shrimp flour. The next in order was corn and wheat based but all were acceptable. The well accepted extruded that were developed in the study can be scaled up for potential commercialization and marketing. Extrusion of cereal flour with shrimp protein can be used to produce high-protein products that would be an option to provide nutrient snacks for consumers and to increase fish consumption.

\section{ACKNOWLEDGMENTS}

This research was carried out at the Department of Harvest and Post-Harvest Technology, College of Fisheries, Junagadh Agricultural University. The authors thanks that the staff of Harvest and Post-Harvest Technology for their advice and assistance.

\section{REFERENCES}

Ali, M.Y., Mahmud, Z., Rashed, A., Khanom, M. and Sarower, G. (2013). Post-harvest quality loss of shrimp (Penaeus monodon) in the value chain of southwestern region (satkhira) in Bangladesh. International Journal of Scientific Knowledge. 3(2):36-44.

AOAC. (2006). Official Methods of Analysis of the Association of Official Analysis 16th edn, Association of Official Anaytical Chemists, Washington DC. Augustin, M.A. and Sanguansri, L. (2003). Polyunsaturated fatty acid: Delivery innovation and incorporation into foods. Food Australia. 55:294-296.

Bamforth, N.W. (2005). Food fermentation and microorganisms. Blackwell publishing company, Oxford, pp 17-18.

Bredie, W.L.P., Mottram, D.S. and Guy, R.C.E. (2002). Effect of temperature and $\mathrm{pH}$ on the generation of flavor volatiles in extrusion cooking of wheat flour. $J$ Agric Food Chem. 50: 1118-1125.

Chaiyakul, S., Jangchud, K., Jangchud, A., Wuttijumnong, P. and Winger R. (2009). Effect of extrusion conditions on physical and chemical properties of high protein glutinous rice-based snack. LWT-Food Science and Technology. 42: 781-787.

Ding, Q.B., Ainsworth, P., Plunkett, A., Tucker, G. and Marson, H. (2006). The effect of extrusion conditions on the functional and physical properties of wheat based expanded snacks. J Food Eng. 73: 142- 148.

Ding, Q.B., Ainsworth, P., Tucker, G. and Marson, H. (2005).The effect of extrusion conditions on the physicochemical properties and sensory characteristics of rice based expanded snacks. J Food Eng. 66: 283-289.

Erickson, M.C., Bulgarelli, M.A., Resurrection, A.V.A., Vendetti, R.A. and Gates, K.A. (2007). Sensory differentiation of shrimp using a trained descriptive analysis panel. Science direct LWT. 40:1774-1783.

FAO. (2011). Fishery and aquaculture statistics. The state of world fisheries and aquaculture. ISSN 2070-6057, pp: 10.

Ferreira, R.E., Chang, Y.K. and Steel, C.J. (2011). Influence of wheat bran addition and of thermoplastic extrusion process parameters on physical properties of corn-based expanded extruded snacks. Alim Nutr Araraquara. 22 (4): $507-520$

Gujska, E. and Khan, K. (1990). Effect of temperature on properties of extrudates from high-starch fractions of navy, pinto and garbanzo beans. J Food Sci. 55: 466-469.

Homchoudhury, M., Chakraborty, R., Sarkar, S. and Raychaudhuri, U. (2012). Characterization of extrudate prepared from rice (Oryza sativa 1) and chapra (Fenneropenaeus indicus) by twin screw extrusion. Fishery Technology. 49: 50 - 53.

Hood-neifer, S.D. and Tyler, R.T. (2010). Effect of protein, moisture content and barrel temperature on the physicochemical characteristics of pea flour extrudates. Food Res Int. 43: 659-663.

Ilo, S. and Berghofer, E. (1999). Kinetics of colour changes during extrusion cooking of maize grits. J Food Eng, Oxford. 39(1): 73-80.

Kumar, N., Sarkar, B.C. and Sharma, H.K. (2010). Development and characterization of extruded product of carrot pomace, rice flour and pulse powder. African Journal of Food Science. 4(11): 703 - 717.

Kuna, A., Lakshmi Devi, N. and Kalpana, K. (2013). Utilization of fish powder in ready-to-eat extruded snacks. Fishery Technology. 50: 245 - 250.

Lakshmidevi, N., Vijaya, K. and Mallikarjun, R. (2005). Development and acceptability of ready to eat snack for the institutionalized elderly. J Food Sci Technol. 42 (2): 176-179.

Larmond, E. (1977). Method for sensory evaluation of food. Publ. No. 1286. Canada dept. of agriculture, Canada, pp 36-37.

Madhusudhan, B. and Tharanathan, R.N. (1995). Legume and cereal starches why differences in digestibility- Part II. Isolation and characterization of starches from rice (O. sativa) and ragi (finger millet, E.coracana). Carbo Polym. 28: 153-158.

Majumdar, R.K. and Singh, R.K. (2012). The effect of extrusion conditions on the physicochemical properties and sensory characteristics of fish-based expanded snacks. Journal of Food Processing and Preservation. doi:10.1111/jfpp.12041.

Murphy, M.G., Skonberg, D.I., Camire, M.E., Dougherty, M.P., Bayer, R.C. and Briggs, J.L. (2003). Chemical composition and physical properties of extruded snacks containing crab-processing by-product. Journal of the Science of Food and Agriculture. 83:1163-1167.

Onwulata, C.I., Smith, P.W., Konstance, R.P. and Holsinger, V.H. (2001). Incorporation of whey products in extruded corn, potato or rice snacks. Food Research International. 34: 679-687.

Shah, A.J. (1991). Extrusion cooking of cod/ com grits. School of food and fisheries studies. Huberside Polytechnic. pp 93-98.

Shaviklo, G.R., Olafsdottir, A., Sveinsdotir, K., Thorkelsson, G. and Rafipour. (2011). Quality characteristics and consumer acceptance of a high fish protein puffed corn fish snack. J Food Sci Technol. 48(6): 668-676.

Shoar, D.Z., Hardacre, A.K. and Brennan, C.S. (2010). The Physico-chemical characteristics of extruded snacks 
enriched with tomato lycopene. Food Chemistry. 123: 1117-1122.

Simopoulos, A.P. (2000). Role of poultry products in enriching the human diet with n-3 PUFA, human requirement for n-3 polyunsaturated fatty acids. Poultry Science. 79: 961-970.

Singh, S., Gamlath and Wakeling, L. (2007). Nutritional aspects of food extrusion. International Journal of Food Science \& Technology. 42 (8): 916-929.

Spigno, G. and Faveri, D.M.D. (2004). Gelatinization kinetics of rice starch studied by non-isothermal calorimetric technique: influence of extraction method, water concentration and heating rate. J Food Engg. 62: 337-344.

Suknark, K., Lee, R.R., Eitenmiller and Phillips, R.D. (2001). Stability of tocopherols and retinyl palmitate insnack extrudates. J. Food Sci. 66: 897-902.

Thymi, S., Krokida, M.K., Pappa, A. and Maroulis, Z.B. (2005). Structural properties of extruded corn starch. Journal of Food Engineering. 68(4): 519-526.

Tumuluru, J.S., Sokhansanj, S., Bandyopadhyay, S. and
Bawa, A.S. (2013). Changes in Moisture, Protein, and fat content of fish and rice Flour coextrudates during single-screw extrusion cooking. Food Bioprocess Technol. 6:403-415.

Veronica, A.Q., Olusola, O.M. and Debowable, E.A. (2006). Qualities of extruded puffed snack from maize/soy bean mixture. J Food Process Eng. 29: 149-161.

Virgilo, R., González, C., Mendoza, S., Avendano, S. and Munoz N. (2006). Bacteriological analysis of frozen shrimps: total plate count-coliforms and enterococci in precooked frozen chilean shrimp. Journal of Food Science. 35(6): 842-844.

Wang, N., Bhirud, P.R. and Tyler, R.T. (1999). Extrusion texturization of air classified pea protein. J. Food Sci. 64: 509-513.

Yagci, S. and Goguş, F. (2008). Response surface methodology for evaluation of physical and functional properties of extruded snack foods developed from food-byproducts. Journal of Food Engineering. 86: 122-132. 